\title{
Effect of air-polishing on surface roughness of composite dental restorative material - comparison of three different air-polishing powders
}

\author{
Joanna Janiszewska-Olszowska ${ }^{{ }^{* \dagger}} \mathbb{D}$, Agnieszka Drozdzik ${ }^{1 \dagger}$, Katarzyna Tandecka ${ }^{2}$ and Katarzyna Grocholewicz ${ }^{1}$
}

\begin{abstract}
Background: Increased composite roughness enhances bacterial adhesion and discoloration, thus increasing the risk of gingival inflammation and secondary caries. Concerns about detrimental effects of sodium bicarbonate on surface roughness influenced the development of less abrasive powders: a glycine-based powder and an erythritolbased powder, additionally - sodium bicarbonate-based powder of reduced grain size. However, there is limited evidence on effects of these materials on the surface of dental fillings. The aim of the present study was to compare the effects of three air-polishing powders (of a reduced abrasiveness) on surface roughness of microhybrid restorative composite material.
\end{abstract}

Material and methods: Microhybrid light-cure resin composite samples were placed on 64 plaster cubes and light-cured through polyester strips. Surface roughness was measured using laser confocal microscope (magnification 2160x). The specimens were randomly divided into three groups ( $n=20,20$ and 24) and airpolished with: sodium bicarbonate $(40 \mu \mathrm{m})$, glycine $(25 \mu \mathrm{m})$ and erythritol $(14 \mu \mathrm{m})$, respectively. Then surface roughness was remeasured, keeping the same field of observation. Specialized 3D analysis software was used for data processing. Parameters according to ISO 25178: Sa, Sq, Sku, Sp, Sv, Sz, Ssk were used to describe surface roughness.

Results: Sa, Sq, Sp, Sv, Sz increased significantly following air polishing. Ssk was significantly higher, whereas Sku was significantly lower in sodium bicarbonate and erythritol groups than before air polishing. Comparison between the three powders revealed that Sa was significantly higher in sodium bicarbonate group than in glycine group. Sku was significantly higher in glycine and erythritol groups than in sodium bicarbonate group. Conclusions: Sodium bicarbonate has a stronger detrimental effect on composite surface than glycine or erythritol. No advantage of erythritol comparing to glycine could be found.

Keywords: Sodium bicarbonate, Glycine, Erythritol, Prophylaxis, Filling

\footnotetext{
* Correspondence: jjo@pum.edu.pl

†Joanna Janiszewska-Olszowska and Agnieszka Drozdzik are equal first

authors

${ }^{1}$ Department of Interdisciplinary Dentistry Pomeranian Medical, University in

Szczecin, al. Powstancow Wlkp, 72, 70-111 Szczecin, Poland

Full list of author information is available at the end of the article
}

(c) The Author(s). 2020 Open Access This article is distributed under the terms of the Creative Commons Attribution 4.0 International License (http://creativecommons.org/licenses/by/4.0/), which permits unrestricted use, distribution, and

reproduction in any medium, provided you give appropriate credit to the original author(s) and the source, provide a link to the Creative Commons license, and indicate if changes were made. The Creative Commons Public Domain Dedication waiver (http://creativecommons.org/publicdomain/zero/1.0/) applies to the data made available in this article, unless otherwise stated. 


\section{Introduction}

Hygiene maintenance therapy is a crucial part of periodontal and restorative treatment [1-3]. Biofilm and tooth deposits are usually repeatedly removed at regular intervals, even in patients with low risk of periodontal diseases and caries development. There are several procedures for plaque and extrinsic stains removal, among them application of slurry of pressurized air, abrasive powder and water (air-polishing), as alternatives to conventional techniques. Air-polishing, as compared with the use of rubber cups, hand and ultrasonic scalers, is a highly effective, easy and rapid technique [4-8]. It causes less operator fatigue, and improves access to hardly accessible tooth surfaces [8].

The air polishing technology began with the application of sodium bicarbonate based air powders [8]. The conventional sodium bicarbonate powder, with particles up to $250 \mu \mathrm{m}$, is regarded as a high-level abrasive material, carrying a risk to soft and hard tissues as well as restorative materials [8-11]. Air-polishing composite resins with sodium bicarbonate results in a noticeable surface wear [12-16], that may entail both aesthetic and health aspects. Moreover, surface roughness increase occurs, which plays a crucial role in bacterial adhesion and biofilm formation, thus increasing the risk of gingival inflammation and secondary caries [17-20].

Concerns about harmful effects of sodium bicarbonate influenced the development of less abrasive powders [2]. In 2003 a new powder containing glycine and 10 years later, an erythritol-based powder were marketed [21, 22], additionally sodium bicarbonate-base powder with reduced granule-metric size up to $40 \mu \mathrm{m}$ has become available. There is limited information about topical effects of these more recently launched materials. The available studies suggest significantly reduced abrasive effects on composite resins of glycine based than sodium bicarbonate based powders [15].

To the best of authors' knowledge there are no studies evaluating effects of an erythritol powder on composite surface roughness.

The aim of this in vitro study was to compare three different air-polishing powders in terms of their effect on the surface roughness of microhybrid restorative composite material.

\section{Materials and methods}

Microhybrid light-cure resin composite (Charisma, Heraeus Kulzer, Hanau, Germany) samples were placed on 64 plaster cubes, light-cured through polyester strips (Direkta Dental, Upplands Väsby, Sweden) for $40 \mathrm{~s}$ each using dental curing light (T-led, SternWeber, Poland) and numbered in sequence.

The surface roughness of all specimens was measured using a laser confocal microscope (Lext OLS4000,
Olympus) with a 100x lens (MPLAPON100xLEXT), under the magnification $2160 x$. The field of observation and measurement was $128 \mu \mathrm{m} \times 128 \mu \mathrm{m}$. The confocal mode was used to analyse the height information, whereas laser microscope mode was used for sample observation and acquiring images. The measuring units in $\mathrm{z}$-azis were $10 \mathrm{~nm}$. Each sample was aligned according to $\mathrm{x}, \mathrm{y}$ and $\mathrm{z}$ coordinates from the marked starting point using the motorized table of the microscope.

Then the specimens were randomly divided into three groups of 20, 20 and 24 specimens respectively and airpolished, using three different air-polishing powders:

1. Group SB - sodium bicarbonate - Air-Flow Supragingival Comfort Classic (EMS SA, Switzerland),

2. Group G - glycine - Air-Flow Subgingival Perio (EMS SA, Switzerland),

3. Group E - erythritol - Air-Flow Sub + Supragingival Plus (EMS SA, Switzerland).

The average grain sizes of the powders provided by the manufacturer were: $40 \mu \mathrm{m}, 25 \mu \mathrm{m}$ and $14 \mu \mathrm{m}$, respectively. The air-polishing procedure was performed by the same periodontal specialist using the standard unit (Air-Flow Master, EMS SA, Switzerland), according to the manufacturer recommended settings at the pressure of 2.5 bar and with three different powder chambers for each powder. In order to achieve reproducible working conditions powder chambers were refilled to the recommended maximum level after each air-polishing run. The efforts were made to duplicate clinical procedure as much as possible. The standard air polishing nozzle, designed for supragingival application, was used with spraying distance of $3 \mathrm{~mm}$, at $45^{\circ}$ angle between nozzle and specimens surface with spraying time of $5 \mathrm{~s}$ counted down via electronic control of the device. During the application the nozzle was kept in a constantly sweeping movement as in clinical practice.

Then the surface roughness of each sample was remeasured, keeping the same field of observation. Specialized 3D analysis computer software - TalyMap Platinum (Taylorhobson Ltd., USA) was used for data processing, which comprised: surface levelling, non-measured points filling (using a smooth shape calculated from the neighbours) and shape (form) removal. The following height parameters according to ISO 25178 were used to describe composite surface roughness:

$\mathrm{Sa}$ - arithmetical mean height of the surface,

$\mathrm{Sq}$ - root mean square height of the surface,

$\mathrm{Sku}$ - kurtosis of the surface

$\mathrm{Sp}$ - maximum peak height

$\mathrm{Sv}$ - maximum pit depth

$\mathrm{Sz}$ - maximum height of the surface, 
Table 1 Analysis of data normality (Shapiro-Wilk test)

\begin{tabular}{lllll}
\hline Variable & $\begin{array}{l}\text { Before air- } \\
\text { polishing }\end{array}$ & \multicolumn{3}{l}{ After air-polishing } \\
\cline { 3 - 5 } & & Group SB & Group G & Group E \\
\hline Sa & $<0,001^{*}$ & 0,885 & 0,085 & 0,116 \\
Sq & $<0,001^{*}$ & 0,266 & 0,358 & $0,017^{*}$ \\
Sku & $<0,001^{*}$ & $<0,001^{*}$ & $0,001^{*}$ & $<0,001^{*}$ \\
Sp & $<0,001^{*}$ & $0,02^{*}$ & 0,165 & $<0,001^{*}$ \\
Sv & $<0,001^{*}$ & $0,041^{*}$ & 0,223 & $0,001^{*}$ \\
Sz & $<0,001^{*}$ & 0,247 & 0,191 & $<0,001^{*}$ \\
Ssk & $0,021^{*}$ & 0,487 & 0,181 & $0,003^{*}$ \\
\hline
\end{tabular}

${ }^{*} p<0.05$ is evidence of non-normal distribution
Ssk - skewness of height distribution.

Shapiro-Wilk test at the level $\alpha=0.05$ was used in order to check for data normality.

Analysis of variance (ANOVA) was used to compare between variables of normal distribution and for the latter Kruskal-Wallis test. The roughness parameters were compared between the whole sample $(n=64)$ before airpolishing $(\mathrm{C}$ - control) and groups $\mathrm{SB}, \mathrm{G}$ and $\mathrm{E}$ polished with three different powders. Then, surface roughness parameters were compared between the three groups polished with different powders. In order to verify the sample size sample size analysis was performed using an online calculator (powerandsamplesize.com). With the clinical significance of $0,25 \mu \mathrm{m}$ for Sa and Sq, the sample size yielded 20 and 6 , respectively.

Table 2 Distribution of roughness parameters before and after air-polishing

\begin{tabular}{|c|c|c|c|c|c|c|c|c|c|c|c|}
\hline Variable & Group & $\mathrm{N}$ & Mean & SD & Median & Min & Max & Q1 & Q3 & $p^{*}$ & $p^{* *}$ \\
\hline \multirow[t]{4}{*}{ Sa [um] } & Before air-polishing (C) & 64 & 0,03 & 0,02 & 0,02 & 0,01 & 0,1 & 0,02 & 0,03 & $<0,001$ & \\
\hline & Group SB & 20 & 0,28 & 0,11 & 0,28 & 0,04 & 0,5 & 0,23 & 0,34 & & 0,029 \\
\hline & Group G & 20 & 0,18 & 0,11 & 0,21 & 0,03 & 0,36 & 0,09 & 0,27 & $S B, G, E>C$ & $S B>G$ \\
\hline & Group E & 24 & 0,21 & 0,14 & 0,2 & 0,04 & 0,55 & 0,09 & 0,29 & & \\
\hline \multirow[t]{4}{*}{ Sq [um] } & Before air-polishing (C) & 64 & 0,09 & 0,08 & 0,07 & 0,03 & 0,51 & 0,05 & 0,11 & $<0,001$ & \\
\hline & Group SB & 20 & 0,46 & 0,23 & 0,41 & 0,06 & 0,96 & 0,31 & 0,56 & & 0,14 \\
\hline & Group G & 20 & 0,31 & 0,16 & 0,3 & 0,07 & 0,74 & 0,21 & 0,4 & $S B, G, E>C$ & \\
\hline & Group E & 24 & 0,38 & 0,26 & 0,34 & 0,08 & 1,06 & 0,23 & 0,44 & & \\
\hline \multirow[t]{4}{*}{ Sku } & Before air-polishing (C) & 64 & 439,95 & 565,46 & 238,05 & 4,04 & 3733,08 & 142,3 & 539,86 & $<0,001$ & \\
\hline & Group SB & 20 & 31,17 & 52,85 & 13,79 & 3,99 & 244,69 & 7,7 & 30,19 & & 0,016 \\
\hline & Group G & 20 & 104,49 & 115,96 & 35,88 & 4,72 & 365,73 & 17,83 & 171,55 & $C>S B, G, E$ & $\mathrm{G}, \mathrm{E}>\mathrm{SB}$ \\
\hline & Group E & 24 & 132,18 & 262,67 & 73,26 & 6,6 & 1310,53 & 16,49 & 114,43 & & \\
\hline \multirow[t]{4}{*}{$\mathrm{Sp}[\mu \mathrm{m}]$} & Before air-polishing (C) & 64 & 1,65 & 2,26 & 0,93 & 0,13 & 13,49 & 0,41 & 1,85 & $<0,001$ & \\
\hline & Group SB & 20 & 3,75 & 2,7 & 3,45 & 0,56 & 11,9 & 2,14 & 4,82 & & 0,775 \\
\hline & Group G & 20 & 3,29 & 2,12 & 3,19 & 0,52 & 9,02 & 1,7 & 4,78 & $\mathrm{SB}, \mathrm{G}, \mathrm{E}>\mathrm{C}$ & \\
\hline & Group E & 24 & 3,99 & 3,18 & 3,53 & 0,22 & 15,83 & 1,76 & 5,28 & & \\
\hline \multirow[t]{4}{*}{ Sv [um] } & Before air-polishing (C) & 64 & 3,39 & 2,9 & 2,73 & 0,83 & 17,68 & 1,47 & 4,08 & $<0,001$ & \\
\hline & Group SB & 20 & 4,82 & 2,48 & 3,91 & 1,89 & 10,89 & 2,69 & 6,95 & & \\
\hline & Group G & 20 & 4,61 & 2,02 & 4,91 & 1,74 & 8,1 & 2,6 & 6,08 & $\mathrm{SB}, \mathrm{G}, \mathrm{E}>\mathrm{C}$ & 0,798 \\
\hline & Group E & 24 & 5,44 & 3,3 & 4,34 & 1,81 & 15,25 & 3,1 & 6,78 & & \\
\hline \multirow[t]{4}{*}{ Sz [um] } & Before air-polishing (C) & 64 & 5,04 & 4,66 & 4,16 & 1,01 & 31,17 & 2,39 & 5,52 & $<0,001$ & \\
\hline & Group SB & 20 & 8,58 & 4,28 & 7,97 & 2,48 & 19,07 & 5,5 & 10,65 & & \\
\hline & Group G & 20 & 7,9 & 3,12 & 6,56 & 3,15 & 13,84 & 6,02 & 10,27 & $\mathrm{SB}, \mathrm{G}, \mathrm{E}>\mathrm{C}$ & 0,77 \\
\hline & Group E & 24 & 9,43 & 5,58 & 8,56 & 3,64 & 31,08 & 6,31 & 10,4 & & \\
\hline \multirow[t]{4}{*}{ Ssk } & Before air-polishing (C) & 64 & $-8,89$ & 12,05 & $-8,97$ & $-47,86$ & 24,53 & $-15,17$ & $-2,68$ & $<0,001$ & \\
\hline & Group SB & 20 & $-0,94$ & 3,06 & $-0,57$ & $-8,98$ & 5,06 & $-2,61$ & 0,09 & & 0,395 \\
\hline & Group G & 20 & $-4,04$ & 5,91 & $-1,87$ & $-15,82$ & 6,29 & $-8,16$ & 0,48 & $S B, E>C$ & \\
\hline & Group E & 24 & $-3,26$ & 6,62 & $-1,35$ & $-25,23$ & 4,72 & $-6,68$ & 0,72 & & \\
\hline
\end{tabular}

* Kruskal-Wallis test + post- hoc analysis (Dunn test)

** ANOVA + post-hoc analysis (Fisher's LSD test) for Sa, Kruskal-Wallis test + post-hoc analysis (Dunn test) for the latter variables 


\section{Results}

Data normality has been presented in Table 1 . Most data were characterized by a non-normal distribution.

No statistically significant differences (ANOVA) were found between the study groups before air-polishing, thus further comparisons were made between the whole sample before air-polishing $(n=64)$ and groups SB, G and $\mathrm{E}$ after air-polishing.

The distribution of the roughness parameters before and after air-polishing is presented in Table 2, whereas raw data - as a Additional file 1. Typical composite surfaces from each group of specimen are presented in Figs. 1, 2 and 3. All variables compared were significantly different $(p<0.05)$ after air-polishing for all the groups analysed. A post-hoc analysis (Dunn test) proceeded proved that:

- Sa, Sq, Sp, Sv, Sz were significantly higher in groups $\mathrm{SB}, \mathrm{G}$ and $\mathrm{E}$ than before air polishing,

- Ssk was significantly higher in groups SB and E than before air polishing,

- Sku was significantly lower in groups SB, G and E than before air polishing.

Comparing between the three powders, it has been found that:

- Sa was significantly higher in group SB than in group G

- Sku was significantly higher in groups G and E than in group $\mathrm{SB}$.

\section{Discussion}

The present in vitro study provides comprehensive information about the effects of three commercially available types of air-polishing powders, i.e. sodium bicarbonate-, glycine- and erythritol- based on the surface roughness of microhybrid composite resin used for dental restorations. All tested powders, although characterized by a reduced abrasiveness, caused a statistically significant increase in surface roughness. Various composite materials may have different resins and contain filler particles of different size and composition. Thus surface susceptibility to damage may differ. Moreover, it is known, that surface roughness is material dependent. Thus the purpose of this study was to assess and compare the effect of air-polishing powders on one composite resin material, which is currently used in a daily practice for anterior and posterior restorations.

The use of a confocal microscope has the advantage of objective quantitative measuring $3 \mathrm{D}$ roughness parameters of the surface. However, the surface alteration caused by air-polishing would be also visible in scanning electron microscopy.

The surface texture of composites has influence on plaque accumulation, discoloration and wear [23]. Decreased bacterial adhesion was observed at surface roughness of $0.15 \mu \mathrm{m}$ [24]. Moreover, the tip of the tongue is able to detect a surface roughness change of $0.3 \mu \mathrm{m}$, thus a smooth surface adds to the patient's comfort [25]. Furthermore, the final surface polish influences the aesthetics of composite restorations and contributes to the gloss meter [26] as well as a better color stability [27].
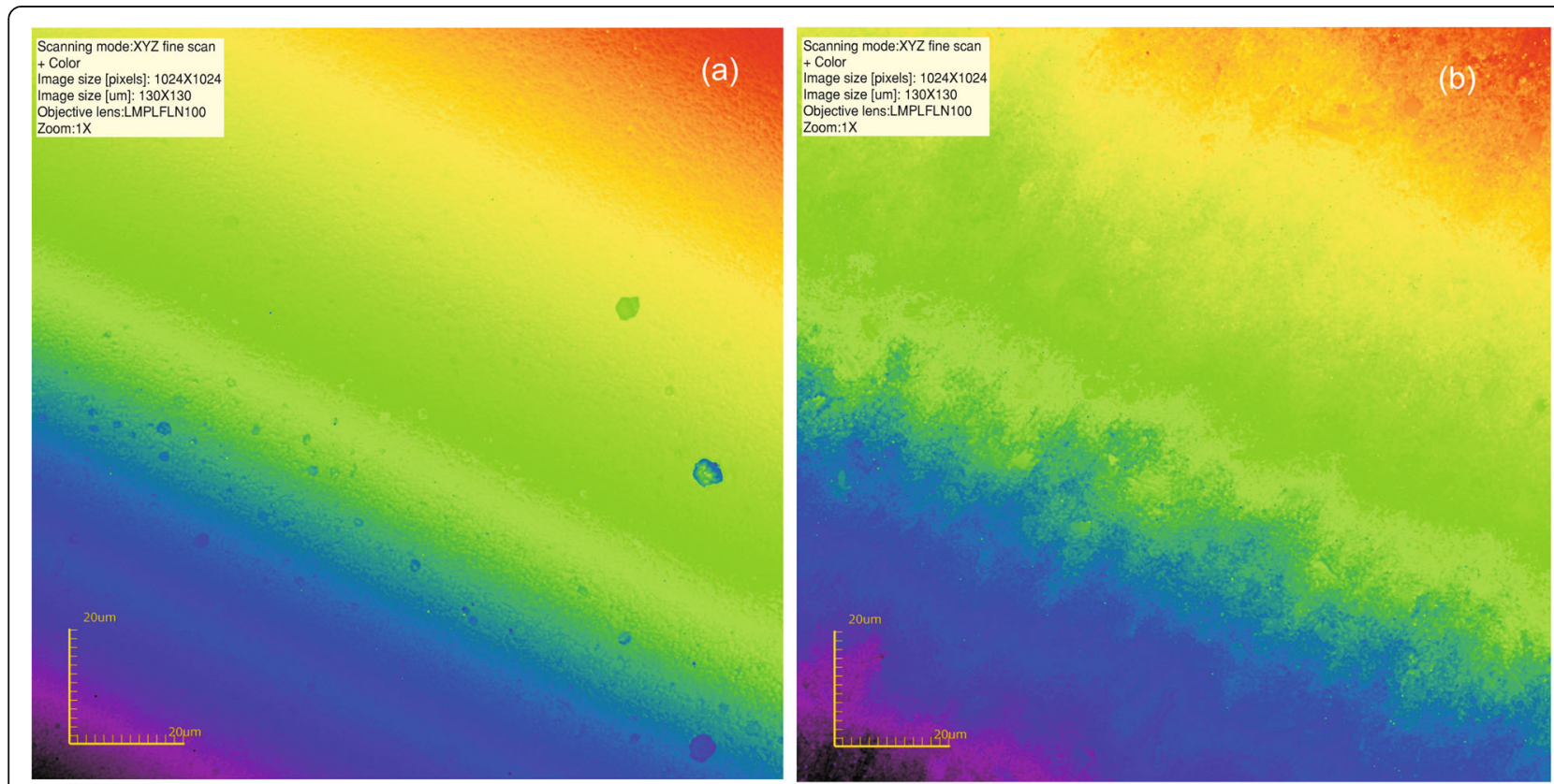

Fig. 1 a Typical composite surface; b Following air-polishing with sodium bicarbonate 


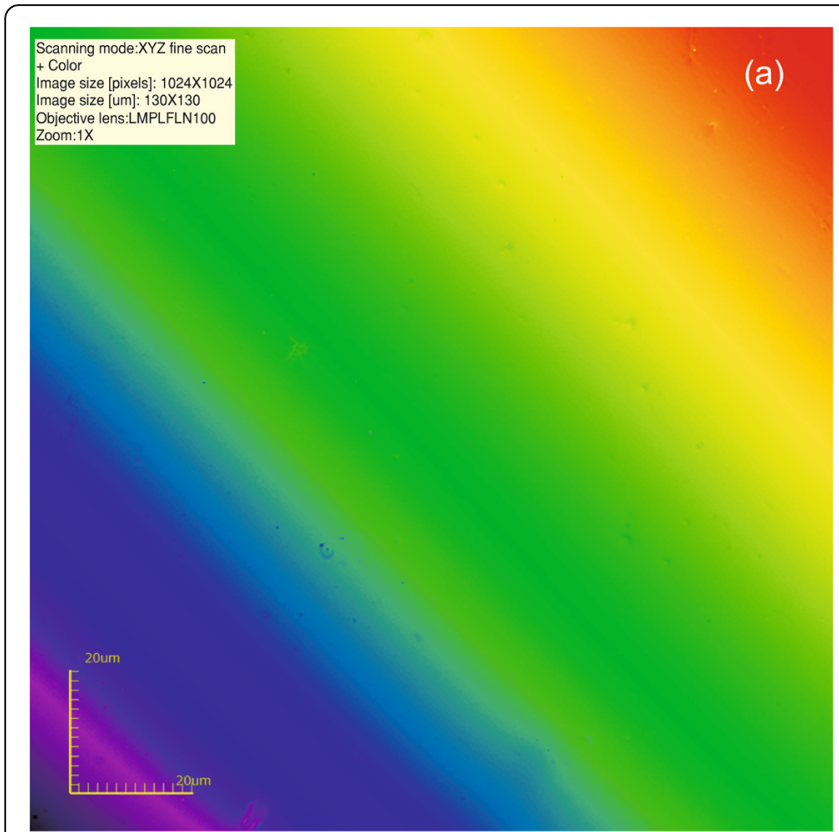

Fig. 2 a Intact composite surface; b Following air-polishing with glycine

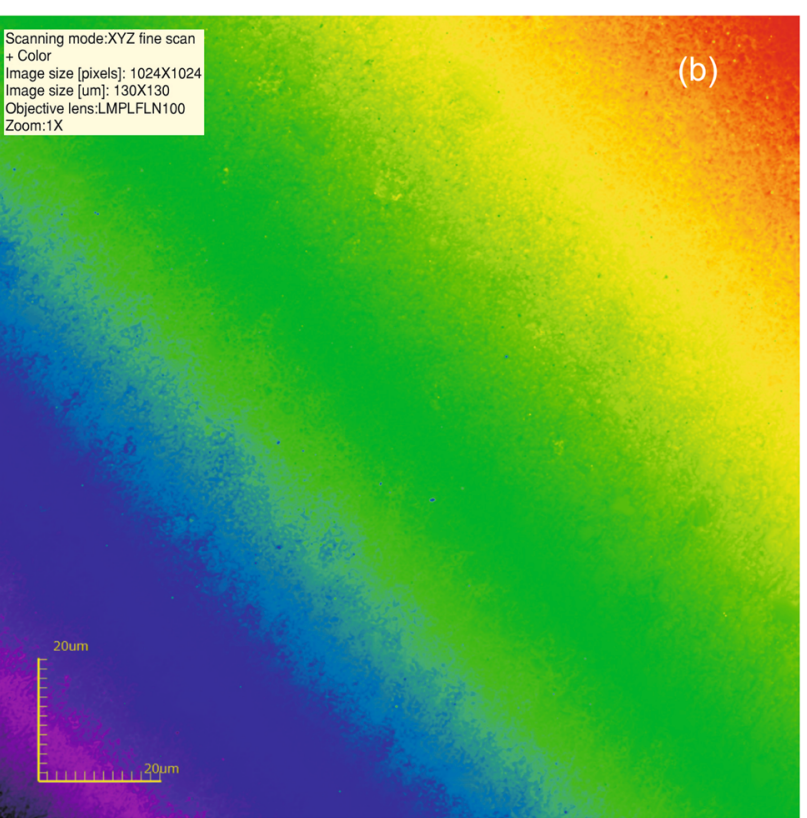

It is believed that smoothest surface is obtained when composite is polymerized against a matrix strip. Clinically, composite restorations may present a high variety of finishing and polishing quality. Moreover, through the time in the oral cavity bacterial esterases can degrade composites, thereby increasing the surface roughness of restorations $[28,29]$. In the present study, smooth composite surfaces were produced by the use of matrix strips in order to obtain a uniformity of the initial roughness. However, it can be supposed, that clinically, the initial as well as the posttreatment surfaces could be much rougher.

Air-polishing composite resin could potentially influence its hardness. However, no studies concerning influence of air-polishing on composite resin nanohardness or wear properties could be found. It has
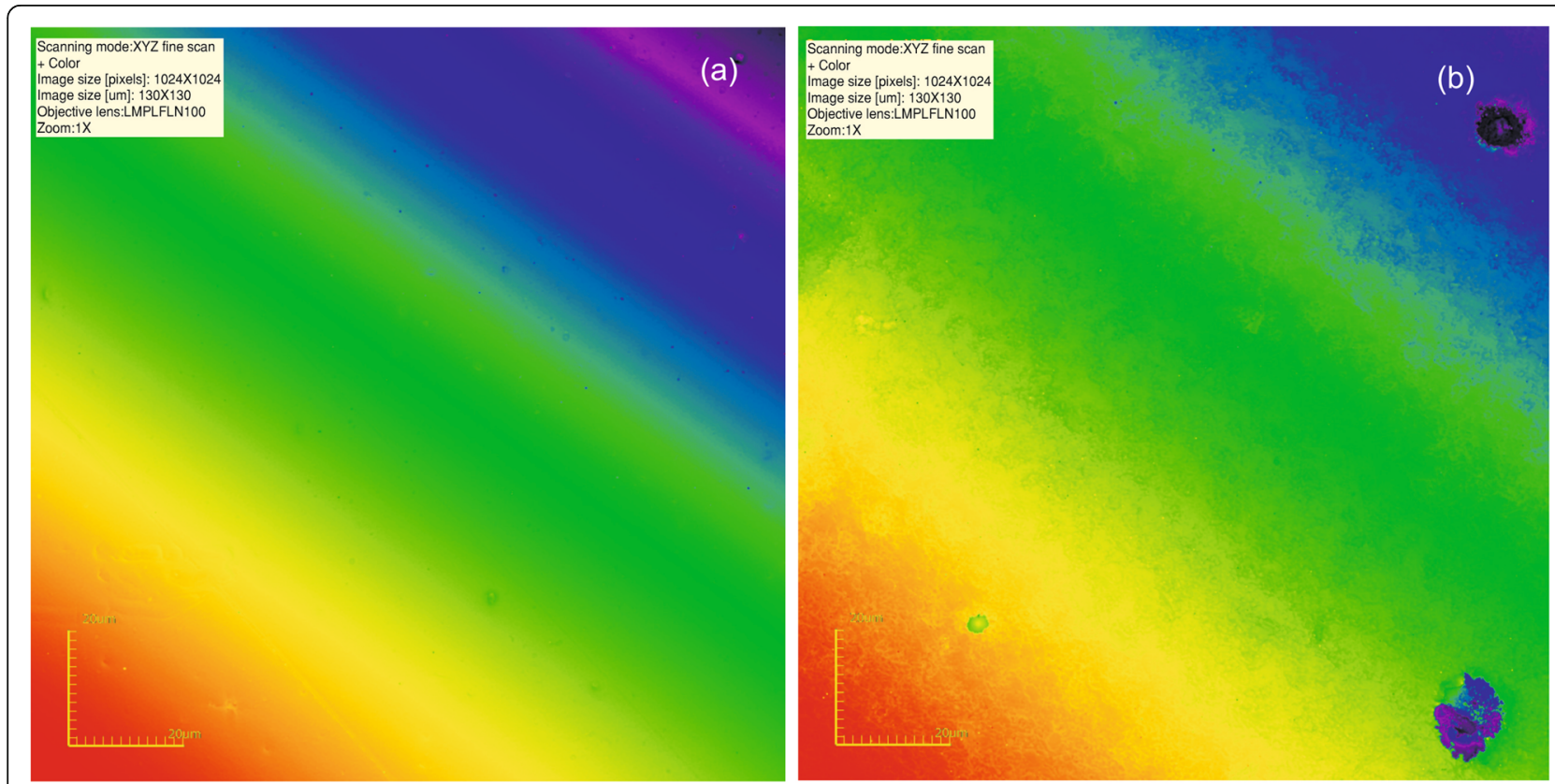

Fig. 3 a Composite surface before air-polishing; b Following air-polishing with erythritol 
been found that the smoothest composite surface obtained under a polyester matrix rich in organic resin is characterized by a lower hardness than following finishing procedures $[30,31]$. Finishing procedures applied to different composites may produce surfaces of various roughness and hardness [31]. Understanding the effect of air-polishing on the microhardness of finished composite surface would require a thorough study.

Increased roughness is a sign of surface damage. Surface damage resulting from kinetic abrasion is influenced by the characteristics of the particles applied. The greater the particle size, hardness and angularity, the more abrasive the slurry [32].

The study evaluated powders based on sodium bicarbonate, glycine and erythritol, with a reduced grain size of $40 \mu \mathrm{m}, 25 \mu \mathrm{m}$ and $14 \mu \mathrm{m}$ respectively. On the Mohs hardness scale the sodium bicarbonate rank 2.8 and glycine and erythritol 2 [33]. Reduction in micron size and hardness enabled safe removal of biofilm and stains above and below the gum line.

The fact that arithmetical mean height of the surface $(\mathrm{Sa})$, root mean square height of the surface $(\mathrm{Sq})$, maximum peak height (Sp), maximum pit depth (Sv) and maximum height of the surface $(\mathrm{Sz})$ were higher in all three experimental groups than before air polishing reflects a significant degree of surface damage resulting from air-polishing.

The surface skewness represents the degree of symmetry of the surface heights about the mean plane. Ssk $<0$ indicates the predominance of valley structures. Ssk had a negative value before air-polishing, which increased significantly in groups SB and E after air polishing. However, no statistically significant differences were found between the three powders.

Sku values above 3.0 indicate the presence in inordinately deep peaks or valleys. The fact that it was significantly reduced in all groups after air-polishing reflects a modification of the composite resin surface. Sku was significantly higher in groups $\mathrm{G}$ and $\mathrm{E}$ than in group $\mathrm{SB}$, showing the highest surface damaging potential of bicarbonate comparing to the other powders tested. It seems that glicyne and erythritol have a similar surface-damaging potential. No other studies including erythritol powder could be found for comparison.

\section{Conclusion}

It can be concluded that the sodium bicarbonatebased air-polishing powder has a stronger detrimental effect on composite surface in terms of its roughness compared to erythritol and glicyne. No advantage of erythritol-based powder comparing to glicyne could be found in this study.

\section{Supplementary information}

Supplementary information accompanies this paper at https://doi.org/10. 1186/s12903-020-1007-y.

Additional file 1. Roughness parameters.

Acknowledgements

None.

Authors' contributions

JJO, AD - study conception and design, data interpretation, writing

manuscript. KT - confocal microscopy and data processing, participation in data interpretation. KG - critical revising for intellectual content. All authors have read and approved the final version of the manuscript.

\section{Authors' information}

JJO is a practising orthodontist and associate professor Department of Interdisciplinary Dentistry

$\mathrm{AD}$ is a practising specialist in periodontology and associate professor Department of Interdisciplinary Dentistry

$\mathrm{KT}$ is engineer scientist and assistant professor Department of Fine Mechanics.

KG is a practising specialist in prosthetic dentistry, head of Department of Interdisciplinary Dentistry

\section{Funding}

This research did not receive any specific grant from funding agencies in the public, commercial, or not-for-profit sectors.

Availability of data and materials

Raw data has been submitted as a supplemental file.

Ethics approval and consent to participate

Not applicable.

Consent for publication

Not applicable.

Competing interests

The authors declare that they have no competing interests.

\section{Author details}

${ }^{1}$ Department of Interdisciplinary Dentistry Pomeranian Medical, University in Szczecin, al. Powstancow Wlkp, 72, 70-111 Szczecin, Poland. Faculty of Mechanical Engineering Koszalin, University of Technology, ul, Raclawicka 15-17, 75-620 Koszalin, Poland.

Received: 14 September 2019 Accepted: 14 January 2020

Published online: 30 January 2020

\section{References}

1. Westfelt E. Rationale of mechanical plaque control. J Clin Period. 1996;23: 263-7.

2. Müller N, Moëne R, Cancela JA, Mombelli A. Subgingival air-polishing with erythritol during periodontal maintenance: randomized clinical trial of twelve months. J Clin Period. 2014:41:883-9.

3. Cobb CM, Daubert DM, Davis K, Deming J, Flemmig TF, Pattison A, Roulet JF, Stambaugh RV. Consensus conference findings on Supragingival and subgingival air polishing. Compend Contin Educ Dent. 2017;38:e1-e4.1.

4. Petersilka GJ, Tunkel J, Barakos K, Heinecke A, Häberlein I, Flemmig TF. Subgingival plaque removal at interdental sites using a low-abrasive air polishing powder. J Clin Period. 2003:74:307-11.

5. Petersilka GJ, Steinmann D, Häberlein I, Heinecke A, Flemmig TF. Subgingival plaque removal in buccal and lingual sites using a novel low abrasive air-polishing powder. J Clin Period. 2003:30:328-33.

6. Flemmig TF, Hetzel M, Topoll H, Gerss J, Haeberlein I, Petersilka G. Subgingival debridement efficacy of glycine powder air polishing. J Clin Period. 2007;78:1002-10.

7. Sculean A, Bastendorf KD, Becker C, Bush B, Einwag J, Lanoway C, Platzer U, Schmage P, Schoeneich B, Walter C, Wennström JL, Flemmig TF. A 
paradigm shift in mechanical biofilm management? Subgingival air polishing: a new way to improve mechanical biofilm management in the dental practice. Quintessence Int. 2013;44:475-7.

8. Graumann SJ, Sensat ML, Stoltenberg J. Air polishing: a review of current literature. J Dent Hyg. 2013;87:173-80.

9. Petersilka G, Faggion CM Jr, Strattmann U, Gerss J, Ehmke B, Haeberlein I, Flemmig TF. Effect of glycine powder air-polishing on the gingiva. J Clin Period. 2008:35:324-32

10. Pelka M, Trautmann S, Petschelt A, Lohbauer U. Influence of air-polishing devices and abrasives on root dentin- an in vitro confocal laser scanning microscope study. Quintessence Int. 2010;41:141-8.

11. Petersilka GJ. Subgingival air-polishing in the treatment of periodontal biofilm infections. Periodontology 2000. 2011;55:124-42.

12. Giacomelli L, Salerno M, Derchi G, Genovesi A, Paganin PP, Covani U. Effect of air polishing with glycine and bicarbonate powders on a nanocomposite used in dental restorations: an in vitro study. Int $J$ Period Rest Dent. 2011:31:e51-6.

13. Arabaci T, Ciçek Y, Ozgöz M, Canakçi V, Canakçi CF, Eltas A. The comparison of the effects of three types of piezoelectric ultrasonic tips and air polishing system on the filling materials: an in vitro study. J Dent Hyg. 2007;5:205-10.

14. Engel S, Jost-Brinkmann PG, Spors CK, Mohammadian S, Müller-Hartwich R Abrasive effect of air-powder polishing on smoothsurface sealants. J Orofac Orthop. 2009:70:363-70.

15. Pelka MA, Altmaier K, Petschelt A, Lohbauer U. The effect of air-polishing abrasives on wear of direct restoration materials and sealants. J Am Dent Assoc. 2010;141:63-70

16. Salerno M, Giacomelli L, Derchi G, Patra N, Diaspro A. Atomic force microscopy in vitro study of surface roughness and fractal character of a dental restoration composite after air-polishing. Biomed Eng Online. 2010;12:9-59.

17. Quirynen M. The clinical meaning of the surface roughness and the surface free energy of intraoral hard substrata on the microbiology of the supraand subgingival plaque: result of in vitro and in vivo experiments. J Dent. 1994;22(Suppl.1S):13-6.

18. Marigo L, Rizzi M, La Torre G, Rumi G. 3-D surface profile analysis: different finishing methods for resin composites. Oper Dent. 2001;26:562-8.

19. Teughels W, Van Assche N, Sliepen I, Quirynen M. Effect of material characteristics and/or surface topography on biofilm development. Clin Oral Implants Res. 2006;17(Suppl 2):68-81.

20. Schmitt VL, Puppin-Rontani RM, Naufel FS, Nahsan FP, Alexandre Coelho Sinhoreti M, Baseggio W. Effect of the polishing procedures on color stability and surface roughness of composite resins. ISRN Dent. 2011:617672. https://doi.org/10.5402/2011/617672.

21. Petersilka GJ, Bel M, Haberlein I, Mehl A, Hickel R, Flemmig TF. In vitro evaluation of novel low abrasive air polishing powders. J Clin Period. 2003; 30(1):9-13.

22. Hägi TT, Hofmänner P, Salvi GE, Ramseier CA, Sculean A. Clinical outcomes following subgingival application of a novel erythritol powder by means of air polishing in supportive periodontal therapy: a randomized, controlled clinical study. Quintessence Int. 2013;44:753-61.

23. Glauser S, Astasov-Frauenhoffer M, Müller JA, Fischer J, Waltimo T, Rohr N. Bacterial colonization of resin composite cements: influence of material composition and surface roughness. Eur J Oral Sci. 2017;125:294-302. https://doi.org/10.1111/eos.12355.

24. Park JW, An JS, Lim WH, Lim BS, Ahn SJ. Microbial changes in biofilms on composite resins with different surface roughness: An in vitro study with a multispecies biofilm model. J Prosthet Dent. 2019;122:493.e1-8. https://doi. org/10.1016/j.prosdent.2019.08.009 Epub 2019 Oct 21.

25. Jones CS, Billington RW, Pearson GJ. The in vivo perception of roughness of restorations. Br Dent J. 2004;196:42-5.

26. Carvalho Andrade K, Pavesi Pini NI, Dias Moda M, de Souza E Silva Ramos F, Dos Santos PH, Fraga Briso AL, Cestari Fagundes T. Influence of different light-curing units in surface roughness and gloss of resin composites for bleached teeth after challenges. J Mech Behav Biomed Mater. 2019;3(102): 103458. https://doi.org/10.1016/j.jmbbm.2019.103458 [Epub ahead of print]

27. Rizzante FAP, Bombonatti JSF, Vasconcelos L, Porto TS, Teich S, Mondelli RFL. Influence of resin-coating agents on the roughness and color of composite resins. J Prosthet Dent. 2019;122:332.e1-5. https://doi.org/10. 1016/j.prosdent.2019.05.011 Epub 2019 Aug 2.

28. Nedeljkovic I, De Munck J, Ungureanu AA, Slomka V, Bartic C, Vananroye A Clasen C, Teughels W, Van Meerbeek B, Van Landuyt KL. Biofilm-induced changes to the composite surface. J Dent. 2017;63:36-43. https://doi.org/10. 1016/j.jdent.2017.05.015

29. Teughels W, Van Meerbeek B, Van Landuyt KL. Biofilm-induced changes to the composite surface. J Dent. 2017;63:36-43. https://doi.org/10.1016/j.jdent. 2017.05.015. 20.

30. Erdemir U, Sancakli HS, Yildiz E. The effect of one-step and multi-step polishing systems on the surface roughness and microhardness of novel resin composites. Eur J Dent. 2012;6:198-205.

31. Pala K, Tekçe N, Tuncer $S$, Serim ME, Demirci M. Evaluation of the surface hardness, roughness, gloss and color of composites after different finishing/ polishing treatments and thermocycling using a multitechnique approach. Dent Mater J. 2016;35:278-89.

32. Neme AL, Frazier KB, Roeder LB, Debner TL. Effect of prophylactic polishing protocols on the surface roughness of esthetic restorative materials. Oper Dentistry. 2002;27:50-8.

33. Lennemann T. Air polishing: overview. Can J Dent Hyg. 2011;45:145-8.

\section{Publisher's Note}

Springer Nature remains neutral with regard to jurisdictional claims in published maps and institutional affiliations.
Ready to submit your research? Choose BMC and benefit from:

- fast, convenient online submission

- thorough peer review by experienced researchers in your field

- rapid publication on acceptance

- support for research data, including large and complex data types

- gold Open Access which fosters wider collaboration and increased citations

- maximum visibility for your research: over $100 \mathrm{M}$ website views per year

At BMC, research is always in progress.

Learn more biomedcentral.com/submissions 